\title{
Remarks on the Historical Development and Syntax of the Copula in North-Eastern Neo-Aramaic Dialects
}

\author{
Geoffrey Khan \\ Cambridge University, Cambridge, United Kingdom \\ gkıoı@cam.ac.uk
}

\begin{abstract}
This paper examines some aspects of the morphology and syntax of the copula in the North-Eastern Neo-Aramaic (NENA) dialects. The first part proposes a possible pathway for the diachronic development of the morphology of the copula, with particular attention to the innovative inflection of the $3^{\text {rd }}$ person. It is argued that this originated in deictic constructions that were reanalysed as deictic copulas. The second part offers a functional explanation for the position of the copula before or after the predicate. It is argued that many constructions that place the copula before the predicate should be interpreted as thetic sentences, whereas those that place the copula after the predicate should be interpreted as categorical sentences. The thetic structures are likely to have developed by the replication of the pattern of copula constructions in Kurdish.
\end{abstract}

\section{Keywords}

Neo-Aramaic- copula- thetic sentence- relative clause

In the North-Eastern Neo-Aramaic (NENA) dialects the equivalent of the English verb 'to be' in a present tense realis predication consists of a copula that is typically attached as a clitic to the predicate. ${ }^{1}$ The predicate may be ascriptive, locational or identificatory, e.g. ${ }^{2}$

C. Qaraqosh:

$$
\begin{aligned}
& \text { báb-i kpina=ila } \\
& \text { father-my hungry=COP.3MS } \\
& \text { 'My father is hungry' } \\
& \text { báb-i } \quad b \text {-bè̀a=ila } \\
& \text { father-my in-house=COP.3MS } \\
& \text { 'My father is in the house' } \\
& \text { 'áwa náša bàb-an=ila } \\
& \text { that man father-our=COP.3MS }
\end{aligned}
$$

\footnotetext{
${ }^{1}$ I am grateful for the perceptive comments of the two anonymous reviewers of the paper, which have helped me improve it in places. ${ }^{2}$ In the names of dialects, Christian and Jewish dialects are indicated by the abbreviations C. and J. respectively. Glossing abbreviations not contained in the standard Leipzig list include: $\mathrm{EZ}=$ ezafe, CST = construct (affix marking head of genitive construction).

${ }^{3}$ Geoffrey Khan, The Neo-Aramaic Dialect of Qaraqosh, Studies in Semitic Languages and Linguistics 36 (Boston, MA: Brill, 2002).
} 
The historical background of the NENA copula and its function have been examined in various previous publications, e.g. Nöldeke, ${ }^{4}$ Goldenberg, ${ }^{5}$ Cohen, ${ }^{6}$ and Khan. ${ }^{7}$ In this paper I shall present some new data and also new interpretations of its historical development and of the function of the various syntactic structures in which it occurs.

\section{The Morphological Development of the Copula}

Enclitic copulas existed in eastern Middle Aramaic, e.g. Syriac: ${ }^{8}$

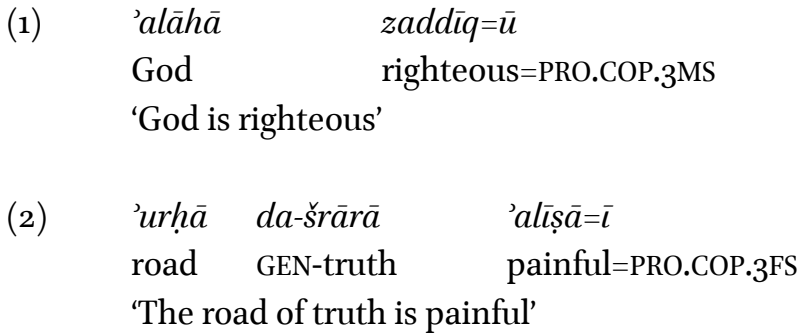

It is clear from the form of the enclitic copula in Syriac that it is in origin an enclitic form of a pronoun. The paradigms of the independent pronouns and their enclitic forms in Syriac are as follows (3). The relationship between the independent and enclitic forms is transparent:

(3) Syriac

\begin{tabular}{|c|c|c|}
\hline & Independent pronoun & Enclitic pronominal copula \\
\hline $3 \mathrm{~ms}$. & $h \bar{u}$ & $=\bar{u}$ \\
\hline 3 fs. & $h \bar{\imath}$ & $=\bar{l}$ \\
\hline $3 \mathrm{mpl}$. & hennōn & $=e n n \bar{n}$ \\
\hline 3fpl. & hennēn & =ennēn \\
\hline $2 \mathrm{~ms}$. & 'att & $=a t t$ \\
\hline 2fs. & 'att & $=a t t$ \\
\hline $2 \mathrm{mpl}$. & 'attūn & $=t t \bar{u} n$ \\
\hline 2fpl. & 'attēn & $=t t \bar{e} n$ \\
\hline 1S.. & 'enā & $=n \bar{a}$ \\
\hline 1 pl. & ḩnan & $=n a n$ \\
\hline
\end{tabular}

\footnotetext{
${ }^{4}$ Grammatik Der Neusyrischen Sprache am Urmia-See und in Kurdistan (Leipzig: T.O. Weigel, 1868) p. 294.

5 'Aramaic Perfects', Israel Oriental Studies 12 (1992), pp.122-123.

6 'The Copular Clause in Jewish Zakho Neo-Aramaic', Journal of Semitic Studies 53 (2008), pp. 43-68.

7 'Quelques Aspects de l'expression d'être' en Néo-Araméen', in Anaïd Donabédian (ed.), Langues de Diaspora. Langues En Contact (Faits de Langues Revue de Linguistique, 18, Paris: Ophrys, 2001) 139-148; Geoffrey Khan, 'Some Aspects of the Copula in North West Semitic', in Steven Fassberg and Avi Hurvitz (eds.), Biblical Hebrew in Its Northwest Semitic Setting: Typological and Historical Perspectives (Jerusalem: Magnes, 2005) 155-176; Geoffrey Khan, 'Remarks on the Historical Development of the Copula in NeoAramaic', in Federico Corriente et al. (eds.), Dialectology of the Semitic Languages Proceedings of the IV Meeting on Comparative Semitics Zaragoza 11/6-9/2010 (Sabadell: AUSA, 2012) 25-31; Geoffrey Khan, 'Grammaticalization of the Copula in North-Eastern NeoAramaic', in Domenyk Eades (ed.), Grammaticalization in Semitic (Journal of Semitic Studies Supplement, 29, Oxford: Oxford University Press, 2012) 109-126.

${ }^{8}$ Rubens Duval, Traité de grammaire syriaque (Paris: F. Vieweg, 1881) p. 362; Theodor Nöldeke, Compendious Syriac Grammar (London: Williams \& Norgate, 1904) p. 246; Gideon Goldenberg, 'On Syriac Sentence Structure', in Michael Sokoloff (ed.), Arameans, Aramaic and the Aramaic Literary Tradition (Ramat-Gan: Bar-Ilan University Press, 1983) pp. 97-140.
} 
Central Neo-Aramaic and Neo-Mandaic, which are the subgroups of Neo-Aramaic that are geographically adjacent to NENA, have retained paradigms of enclitic pronominal copulas that have a reasonably transparent relationship with the independent pronouns:

\begin{tabular}{|c|c|c|c|c|c|c|}
\hline & \multicolumn{2}{|c|}{ Ṭuroyo (Midyat) } & \multicolumn{2}{|c|}{ Țuroyo (Midin) } & \multicolumn{2}{|l|}{ Mlaḥso } \\
\hline & Independent & Enclitic & Independent & Enclitic & Independent & Enclitic \\
\hline $3 \mathrm{~ms}$ & huwe & $=y o$ & hiye & $=y o$ & hiye & $=y o$ \\
\hline $3^{f s}$ & hiya & $=y o$ & hiya & $=y o$ & hiya & $=y o$ \\
\hline 3pl & hanne & $=n e$ & hannak & $=n e$ & hiyen & $=$ ene \\
\hline $2 \mathrm{~ms}$ & hat & $=h a t$ & hat & $=h a t$ & hat & $=h a t$ \\
\hline $2 \mathrm{fs}$ & hat & $=h a t$ & hat & $=h a t$ & hat & $=h a t$ \\
\hline $2 \mathrm{pl}$ & hatu & $=h a t u$ & hatu & $=h a t u$ & hatun & $=$ hatun \\
\hline 1s & 'ŭno & $=n o$ & 'ono & $=n o$ & ’ono & $=$ ono \\
\hline ipl & 'aḥna & $=n a$ & 'aḥna & $=n a$ & 'elana & $=$ ena \\
\hline
\end{tabular}

(5) Modern Mandaic ${ }^{10}$

$\begin{array}{lll} & \text { Independent } & \text { Enclitic } \\ 3 \mathrm{~ms} & \text { huy } & =y e \\ 3 \mathrm{fs} & \text { hid } & =i \\ 3 \mathrm{pl} & \text { honni } & =n \text { 'n } \\ 2 \mathrm{~ms} & \text { ot } & =\text { t } \\ 2 \mathrm{mpl} & \text { aton } & =\text { ton } \\ 1 \mathrm{~s} & \text { 'an, 'ans } & =n o n \\ \mathrm{1pl} & \text { 'ani } & =n i\end{array}$

A factor that clearly had an impact on the development of a copula cliticised to the predicate in the eastern Neo-Aramaic dialects is the existence of clitic copulas as an areal feature in other languages of the region. " Many of these are not Semitic, e.g. Armenian, Turkic languages, Kurdish and other Iranian languages such as Zazaki, ${ }^{12}$ Gorani, ${ }^{13}$ Persian, and also Tatic and Caspian. An enclitic copula is found also in Arabic dialects spoken in south-eastern Turkey and northern Iraq belonging to the so-called qaltu sub-group. ${ }^{14}$ In many Semitic languages of the area the enclitic copula is clearly an enclitic pronoun, this applies to the qaltu Arabic dialects and also, as we have seen, the Țuroyo and Neo-Mandaic sub-groups of Neo-Aramaic.

The morphology of the copula exhibits considerable diversity across the numerous NENA dialects. In contrast to Țuroyo and Neo-Mandaic, in the majority of NENA dialects the paradigm of the enclitic copula does not have a clear morphological relationship to paradigms of independent pronouns. The copula in NENA has converged with the morphology of verbs in various degrees across the different dialects. In the main body of NENA dialects the inflection of the copula exhibits a partial assimilation to that of the verb 'to

\footnotetext{
${ }^{9}$ Helmut Ritter, Ṭūrōyō: Die Volkssprache der Syrischen Christen des Țūr 'Abdīn. C: Grammatik (Stuttgart: Franz Steiner, 199o); Otto Jastrow, Laut- und Formenlehre des Neuaramäischen Dialekts von Mìdin im Ṭūr 'Abdīn (Wiesbaden: Harrassowitz, 1985); Otto Jastrow, Der Neuaramäische Dialekt von Mlahsô (Semitica Viva, 14, Wiesbaden: Harrassowitz, 1994).

${ }^{10}$ Charles Häberl, The Neo-Mandaic Dialect of Khorramshahr (Semitica Viva, 45, Wiesbaden: Harrassowitz, 2009) p. 230.

"Geoffrey Haig and Geoffrey Khan, 'Introduction', in Geoffrey Haig and Geoffrey Khan (eds.), The Languages and Linguistics of Western Asia: An Areal Perspective (The World of Linguistics, 6, Berlin: De Gruyter, 2018) pp. 18-21.

${ }^{12}$ Otto Jastrow, Die Mesopotamisch-Arabischen Qaltu-Dialekte (Wiesbaden: Harrassowitz, 1978) 1, p. 133.

${ }^{13}$ Parwin Mahmoudveysi et al., The Gorani Language of Gawrajūu, a Village of West Iran: Texts, Grammar, and Lexicon (Wiesbaden: Reichert, 2012) para. 2.4.6.

${ }^{14}$ Jastrow, Die Mesopotamisch-Arabischen Qəltu-Dialekte, 1: 131-136; Stephan Procházka, 'The Arabic Dialects of Eastern Anatolia', in Geoffrey Haig and Geoffrey Khan (eds.), The Languages and Linguistics of Western Asia: An Areal Perspective (The World of Linguistics, 6, Berlin: De Gruyter, 2018) 159-189; Stephan Procházka, 'The Arabic Dialects of Northern Iraq', in Geoffrey Haig and Geoffrey Khan (eds.), The Languages and Linguistics of Western Asia: An Areal Perspective (The World of Linguistics, 6, Berlin: De Gruyter, 2018) pp. 243-266.
} 
be' hwy, which is used in modal and future copula clauses. The paradigms of the dialects of C. Qaraqosh and C. Karəmlesh (northern Iraq) are given below:

(6) C. Qaraqosh ${ }^{15}$

\begin{tabular}{|c|c|c|c|}
\hline & Independent Pronoun & Enclitic Copula & hwy \\
\hline $3 \mathrm{~ms}$. & 'ahu & $=i l a$ & hawa \\
\hline $3^{\text {fs. }}$ & 'ahi & $=i l a$ & hawya \\
\hline 3pl. & 'anhan & $=$ ina & hawə \\
\hline $2 \mathrm{~ms}$. & 'ahat & $=i y a t$ & hawat \\
\hline 2fs. & 'ahat & $=$ iyat & hawyat \\
\hline $2 p l$. & 'axtun & =iyetu & hawetu \\
\hline ims. & 'ana & $=i y \partial n$ & hawan \\
\hline ifs. & 'ana & $=i y a n$ & hawyan \\
\hline ipl. & 'axni & $=i y a x$ & hawax \\
\hline
\end{tabular}

(7) C. Karəmlesh (fieldwork by Roberta Borghero)

\begin{tabular}{|c|c|c|c|}
\hline & Independent Pronoun & Enclitic Copula & hwy \\
\hline $3 \mathrm{~ms}$. & 'awan & $=i l a$ & hawa \\
\hline 3 fs. & 'ayən & $=i l a$ & hawya \\
\hline 3pl. & 'ahnən & $=i l e y$ & hawi \\
\hline as. & 'ayat & $=i w a t$ & hawat \\
\hline & 'ayat & $=i w a t$ & hawyat \\
\hline & 'axtun & $=$ iwutun & hawutun \\
\hline & 'ana & $=i w a n$ & hawan \\
\hline & 'ana & $=i w a n$ & hawyan \\
\hline & 'axni & $=i w a x$ & hawax \\
\hline
\end{tabular}

In these two paradigms there is a split between the $3^{\text {rd }}$ person forms, on the one hand, and the $1^{\text {st }}$ and $2^{\text {nd }}$ person forms, on the other. It is the $1^{\text {st }}$ and $2^{\text {nd }}$ person forms that have acquired subject verbal inflection. This is suffixed to the stem $i$-. In C. Karəmlesh the $1^{\text {st }}$ and $2^{\text {nd }}$ person forms have become further assimilated to the verb $h w y$ by acquiring its middle radical $/ w /$.

The inflections of the $3^{\text {rd }}$ person copula, on the other hand, have suffixes containing the element $/ l /$. The 3 pl. form in C. Qaraqosh =ina may have originated from an original $=i-l a$, the $* /$ having shifted to $/ n /$ to distinguish the form from the 3 fs copula -ila.

The / $i /$ stem in the copula paradigms is most easily interpreted as a vestige of an original $3^{\text {rd }}$ person pronominal enclitic copula that can be identified with the $/ y /$ that occurs in the $3^{\text {rd }}$ person singular pronominal enclitic copula of Central Neo-Aramaic (Țuroyo and Mlạso) and Neo-Mandaic. ${ }^{16}$ In Central Neo-Aramaic the $/ y$ / occurs in both the $3 \mathrm{~ms}$ and 3 fs of the pronominal copula, which have the common form $=y o$. This differs from Classical Syriac, in which the 3 ms clitic $(=\bar{u})$ and the 3 fs clitic $(=\bar{l})$ are distinct. It is possible that the $/ y /$ of the $-y o$ clitic in Central Neo-Aramaic originated in the 3 fs clitic and was extended to the $3 \mathrm{~ms}$. A parallel process took place in the independent $3^{\text {rd }}$ person singular pronouns in the village dialects of Turoyo, in which the stem of the 3 fs has been extended to supply the stem of the 3 ms pronoun: hiy- $a$ (3fs), hiy-e (3ms). Contrast the more archaic dialect of Midyat, which preserves distinct stems:

\footnotetext{
${ }^{15}$ Khan, The Neo-Aramaic Dialect of Qaraqosh, pp. 125-126.

${ }^{16}$ Khan, 'Quelques Aspects de l'expression d"être' en Néo-Araméen'.
} 
hiy-a (3fs), huw-e (3ms). In Mlaḥso the stem of the 3 fs independent pronoun has, in fact, been extended also to the 3pl. pronoun: hiy-a (3fs), hiy-e (3ms), hiy-en (3pl). The final /o/vowel in the $3 s$ copula clitic $=y o$ has probably been added by a process of analogical extension of the final $-o$ that is found in demonstrative clitics, e.g. =awo ('that' $3 \mathrm{~ms})$, =ayo ('that' $3 \mathrm{fs}) \cdot{ }^{17}$

The extension of the original $3^{\text {rd }}$ person pronominal element /i/ throughout the paradigm of the enclitic copula indicates that it was no longer analysed as the $3^{\text {rd }}$ person inflection but has been reanalysed as the stem of the copula. One factor that facilitated this development was a recognised process of historical change due to a cross-linguistic tendency for $3{ }^{\text {rd }}$ person singular exponents to be morphologically zero. If a language has a morphologically coded $3{ }^{\text {rd }}$ person singular exponent, this is sometimes reanalysed as part of the stem to which the exponent is attached and the exponent itself is reanalysed as being zero. ${ }^{18}$ An example of such a reanalysis of a $3^{\text {rd }}$ person singular verbal inflection is found in the past tense paradigm of the Clermont-Ferrand dialect of Provençal. ${ }^{19}$ Before the reanalysis, the $3{ }^{\text {rd }}$ person singular exponent was the suffix $-t$. After the reanalysis this became part of the stem and other person exponents were added to it, the $3^{\text {rd }}$ person exponent being analysed as zero:

Past tense of 'to sing' in Provençal (Clermont-Ferrand)

$\begin{array}{lll}\text { Before reanalysis } & \text { After reanalysis } \\ \text { 1s. } & \text { canté- } i & \text { cantét-e } \\ \text { 2s. } & \text { canté-st } & \text { cantét-es } \\ \text { 3s. } & \text { canté-t } & \text { cantét- } \varnothing \\ \text { ipl. } & \text { canté- } m & \text { cantét-em } \\ \text { 2pl. } & \text { canté-tz } & \text { cantét-etz } \\ \text { 3pl. } & \text { canté-ren } & \text { cantét-on }\end{array}$

This tendency for reanalysis of the $3{ }^{\text {rd }}$ person singular exponent as zero has been documented in both verbal and nominal suffixes. It has been explained as being due to the fact that the $3{ }^{\text {rd }}$ person singular is the unmarked exponent of a paradigm and so the optimal iconic morphological coding is zero. ${ }^{20}$ Bybee in her various publications argues that another factor is the frequency of use of such forms, which naturally leads to phonetic reduction. ${ }^{21}$

The original NENA $3^{\text {rd }}$ person singular exponent in the enclitic copula has undergone such a process, which may be represented thus:

$\begin{array}{lll}i & i-\varnothing \\ 3^{S} & \text { stem-3S }\end{array}$

As a result of this reanalysis the stem was generalised throughout the paradigm of the enclitic copula. In the $1^{\text {st }}$ and $2^{\text {nd }}$ persons in the paradigms from C. Qaraqosh and C. Karəmlesh above (6-7) the $i$ - stem is inflected with suffixes that have been formed by analogy with those of the verb $h w y$. In the $3^{\text {rd }}$ person the stem was inflected by suffixes containing an $l$ - element.

\footnotetext{
${ }^{17}$ Nöldeke (Grammatik der Neusyrischen Sprache am Urmia-See und in Kurdistan, p. 294) proposed to derive the NENA enclitic copula from the Aramaic existential particle ${ }^{*} i t$. The derivation of the /i/ of the copula from the $3^{\text {rd }}$-person pronoun is more satisfactory since it brings NENA into line with the pronominal enclitic copulas of the adjacent Neo-Aramaic dialect subgroups.

${ }^{18}$ See Harold Koch, 'The Creation of Morphological Zeroes', in Geert Booij and Jaap van Marle (eds.), Yearbook of Morphology 1994 (Dordrecht: Kluwer, 1995) pp. 31-71 for details.

${ }^{19}$ Joan L. Bybee and M.A. Brewer, 'Explanation in Morphophonemics: Changes in Provençal and Spanish Preterite Forms', Lingua 52 (1980), p. 210.

${ }^{20}$ Koch, 'The Creation of Morphological Zeroes'.

${ }^{21}$ E.g. Joan L. Bybee, Language Usage and Cognition (Cambridge: Cambridge University Press, 2010); Joan L. Bybee, Language Change (Cambridge: Cambridge University Press, 2015).
} 
The suffixes containing $l$ can be identified with the so-called L-suffixes of NENA, which are pronominal phrases containing the preposition $l$ - that express pronominal objects, e.g.

(9) C. Barwar $^{22}$

'aw xaze-le

he sees.3MS-OBJ.3MS

'He sees him'

'aw xaze-la

he sees.3MS-OBJ.3FS

'He sees her'

The explanation as to why these object suffixes should appear in a copula paradigm is that they were extended by analogy from deictic constructions that drew attention to a referent. In such deictic constructions, the perceived $3^{\text {rd }}$ person referent was coded as a direct object, just as it would be in constructions containing a verb of perception ('See him!'). They are similar to deictic constructions such as French voilà or Italian ecco, which may take object complements, e.g. le voilà, eccolo 'There he is'. These are called by Fillmore ${ }^{23}$ 'sentential demonstratives', since they can express a complete sentence. Diessel ${ }^{24}$ discusses a related type of demonstrative which he calls a 'demonstrative identifier'. Judging by the examples he cites from various languages the basic difference between a demonstrative identifier and a sentential demonstrative is that the former is not a complete sentence but requires a complement in the form of a constituent that refers to what is identified. The construction le voilà, therefore, would be a sentential demonstrative consisting of a demonstrative identifier voilà combined with the complement of a 3ms pronominal object suffix.

Țuroyo has a sentential demonstrative that consists of the deictic element $k a$ - and object L-suffixes:

(10) Țuroyo (Midin) $)^{25}$

$\begin{array}{lll}\begin{array}{l}\text { 3ms. } \\ \text { 3fs. }\end{array} & \text { kalé } & \text { 'There he is' } \\ \text { 3pl. } & \text { kalán } & \begin{array}{l}\text { 'There she is' } \\ \text { 'There they are', etc. }\end{array} \\ \text { 2ms. } & \text { kaláx } \\ \text { 2fs. } & \text { kaláx } \\ \text { 2pl. } & \text { kalóxu } \\ & \text { kalí }\end{array}$

In Țuroyo the copula does not have an $/ l /$ element, so the suffixes in this paradigm are unambiguously object suffixes.

In various NENA dialects there are sentential demonstratives that take L-suffixes as their complement. A form that is common to several dialects of northern Iraq and southeastern Turkey is hole. This developed from the combination of the deictic element ho- with the object L-suffix -le. It is likely that the hoelement itself developed historically from * $h \bar{a}-{ }^{\prime} a w$, which is a combination of a deictic element $h \bar{a}$ and a $3 \mathrm{~ms}$ demonstrative pronominal element 'aw 'that one'. The construction * $h \bar{a}^{-}{ }^{\prime} a w$ would, therefore, have itself

\footnotetext{
${ }^{22}$ Geoffrey Khan, The Neo-Aramaic Dialect of Barwar, 3 vols. (Leiden: Brill, 2008) p. 28o.

${ }^{23}$ Charles J. Fillmore, 'Towards a Descriptive Framework for Spatial Deixis', in R. J.Jarvell and W. Klein (eds.), Speech, Place, and Action (Chichester: John Wiley, 1982) p. 47.

${ }^{24}$ Holger Diessel, Demonstratives. Form, Function, and Grammaticalization (Amsterdam: John Benjamins, 1999) pp. $78-88$.

${ }^{25}$ Jastrow, Laut- und Formenlehre des Neuaramäischen Dialekts von Mìdin Im Ṭür 'Abdīn, p. 122.
} 
been originally a sentential demonstrative 'there he is'. In the modern dialects, however, the ho- element acts as the stem for the paradigm of hole, e.g.

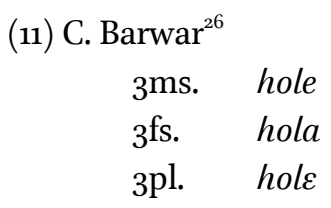

The 3ms 'aw component in the original * $h \bar{a}^{\prime}{ }^{\prime} a w$ construction would, therefore, have undergone a process similar to that of the $3 \mathrm{~s}-i$ element in the enclitic copula, viz. it became reanalysed as a stem followed by a zero $3 \mathrm{~ms}$ exponent, which can be represented as follows (this and further stages of development are numbered for the sake of convenient reference later):

(12) Stage 1

$\begin{array}{lll}* h \bar{a}^{-} a w & \text { *haw- } \varnothing \\ \text { DEIC-PRO.3MS } & & \text { DEIC-3MS }\end{array}$

This would have involved the loss of the referentiality of the original demonstrative pronoun *'aw and the stem *haw would have developed into a spatial deictic. The stem *haw, which underwent further contraction to ho, was then inflected with pronominal object suffixes from the L-suffix series, e.g.

(13) Stage 2
hole
hola
DEIC.OBJ.3MS
DEIC.OBJ.3FS
'There (see) him'
'There (see) her'

The inflection of the form hole was subsequently reanalysed as a copula rather than an object suffix:

(14) Stage 3

hole

DEIC.COP.3MS

'There he is'

This may have been facilitated by contact with the Kurdish dialects in the region, which have sentential demonstrative constructions with copulas, such as the following from the Bahdini Kurdish dialect of Zakho: ${ }^{27}$

(15) wêha=ya

one.over.there $=\mathrm{COP} .3 \mathrm{~S}$

'He is the one over there' = 'There he is'.

In Bahdini Kurdish the demonstrative element in such constructions can have near deixis, e.g.

(16) $\quad a v a ́=y a$

this=COP. $3 \mathrm{~S}$

'He is this one' = 'Here he is'

\footnotetext{
${ }^{26}$ Khan, The Neo-Aramaic Dialect of Barwar, p. 186.

${ }^{27}$ Data supplied by Hiwa Asadpour.
} 
The copula may be $1^{\text {st }}$ or $2^{\text {nd }}$ person, e.g.

(17) $\quad a v a ́=m a$

this-1s.COP I

'I am this one' = 'Here I am'

The use of a demonstrative with a $1^{\text {st }}$ or $2^{\text {nd }}$ person copula suggests that the demonstrative pronoun in such constructions has lost, or is in the process of losing, its referentiality as a $3{ }^{\text {rd }}$ person pronoun and now has, or is in the process of acquiring, the function of a spatial deictic.

Another stimulus to the reanalysis may have been the use of sentential demonstratives such as hole with a locative or attributive adjunct in constructions such as:

$$
\begin{aligned}
& \text { ho.le } \quad g u-b \varepsilon \vartheta a \\
& \text { DEIC.OBJ.3MS in-house } \\
& \text { 'There he is/see him, in the house' }
\end{aligned}
$$

Such constructions draw attention to a referent and append more information about this referent in the adjunct. The construction then underwent a further development whereby the referent and the adjunct became more integrated, with the result that the construction drew attention to a situation involving a referent and locative expression, thus:

$\begin{array}{ll}\text { (19) ho.le } & g u-b \varepsilon \vartheta a\end{array}$

'See him in the house'

This is no longer a sentential demonstrative type of construction but rather a thetic sentence, i.e a sentence that draws attention to a situation. A 'thetic sentence' presents a situation as an undivided whole. This differs from a 'categorical sentence', which consists of the bipartite act of naming an entity and the making a statement about it. ${ }^{28}$ Such thetic sentence constructions are likely to have provided a context that was particularly conducive to the reanalysis of the hole form as a deictic copula.

As a result of this reanalysis the inflectional ending of hole came to be equated with the enclitic copula. This resulted in a process of levelling that had two outcomes. The L-suffix inflection of hole was extended to the enclitic copula, since it was no longer interpreted as an object suffix, i.e. $i-l e$. The form hole then came to be interpreted as consisting of a deictic element and the enclitic copula, i.e. $h o=i l e$, with the /i/contracted:

$\begin{array}{lll}=i \varnothing & > & =i l e \\ =\mathrm{COP} .3 \mathrm{MS} & > & =\text { COP.3MS } \\ \text { hole } & > & \text { hole }(\text { ho }=\text { ile }) \\ \text { DEIC.OBJ.3MS } & & \text { DEIC.COP.3MS }\end{array}$

Some dialects that have hole, in fact, also have an alternative paradigm in which the ile enclitic element is uncontracted, e.g.

(21) C. Barwar ${ }^{29}$

\footnotetext{
${ }^{28}$ Hans-Jürgen Sasse, 'The Thetic/Categorical Distinction Revisited', Linguistics 25 (1987), pp.511-580.

${ }^{29}$ Khan, The Neo-Aramaic Dialect of Barwar, p. 187.
} 


$\begin{array}{ll}3 \mathrm{~ms} & \text { ho=ile } \\ 3 \mathrm{fs} & \text { ho=ila } \\ \text { 3pl } & \text { ho=ile }\end{array}$

These forms are realised phonetically with a glide $/ w /$ between the two vowels, i.e. ['ho:wile], ['ho:willa], ['ho:wille].

As a result of the process of reanalysis labelled stage 3 above (14), the form hole in dialects such as C. Barwar came to function both as a sentential demonstrative and as a deictic copula, which became aligned in its inflection with that of the enclitic copula, and indeed, as we have seen, came to be interpreted as being a construction consisting of a deictic element and enclitic copula. This mutual alignment in inflection is shown clearly by comparing the full two paradigms of hole and the enclitic copula in C. Barwar:

(22) C. Barwar

\begin{tabular}{|c|c|c|}
\hline & Deictic copula & Enclitic copula \\
\hline $3 \mathrm{~ms}$. & hole & $=i l e$ \\
\hline $3^{\text {fs. }}$ & hola & $=i l a$ \\
\hline 3pl. & hole & $=i l \varepsilon$ \\
\hline $2 \mathrm{~ms}$. & hot & $=i w a t,=i t$ \\
\hline 2fs. & hot & $=i w a t,=i t$ \\
\hline $2 p l$. & hotu & $=i w \varepsilon t u,=i t u$ \\
\hline 1ms. & hon & $=i w \partial n,=i n$ \\
\hline 1fs. & hon & $=$ iwan, $=$ in \\
\hline $1 p l$. & hox & $=i w a x,=i x$ \\
\hline
\end{tabular}

In some dialects the deictic copula is only used in the $3^{\text {rd }}$ person, e.g. Umra-Dereköyü. ${ }^{30}$ In dialects that have full paradigms of the deictic copula, moreover, the $3^{\text {rd }}$ person forms occur more frequently in recorded texts than the $1^{\text {st }}$ and $2^{\text {nd }}$ forms. This would explain why the analogical levelling of the L-suffix inflection of sentential demonstratives and the copula, discussed above, applied to the $3^{\text {rd }}$ person.

In C. Barwar there is an alternative paradigm of hole, which is inflected throughout with L-suffixes, including in the $1^{\text {st }}$ and $2^{\text {nd }}$ persons (23). This paradigm may preserve stage 2 of the development described above (13), in which the L-suffix has not yet been reanalysed as an enclitic copula. Another possibility is that the L-suffix in the inflection of the $3^{\text {rd }}$ person copula components has been extended by analogy throughout the paradigm. This could have been facilitated by the common stem ho- of all forms in the paradigm:

(23) C. Barwar ${ }^{1}$

$\begin{array}{ll}\text { 3ms. } & \text { hole } \\ \text { 3fs. } & \text { hola } \\ \text { 3pl. } & \text { hole } \\ \text { 2ms. } & \text { holux } \\ \text { 2fs. } & \text { holax } \\ \text { 2pl. } & \text { holexu } \\ & \\ \text { 1s. } & \text { holi }\end{array}$

$3^{30}$ Sebastian Hobrack, 'Der Neuaramäische Dialekt von Umra (Dere-Köyü). Laut- und Formenlehre. Texte. Glossar' (MA, ErlangenNürnberg, 200o) pp. 42-43.

${ }^{31}$ Khan, The Neo-Aramaic Dialect of Barwar, p. 187. 
1pl.

holax

Some dialects use exclusively a paradigm with extended L-suffixes such as (23). This applies, for example, to many dialects in the northwest of Iraq, such as Peshabur ${ }^{32}$ and Qarawilla, dialects in the region of the Cudi mountain and adjacent areas in southeastern Turkey, such as Bēșpən, ${ }^{33}$ Harbole, Billin, Umra dShish, and some Upper and Lower Tyare dialects and Txuma dialects in southeastern Turkey. ${ }^{34}$

In some dialects the sentential demonstrative/deictic copula cognate with hole underwent further developments. In the dialect of Bohtan described by Fox, ${ }^{35}$ for example, the sentential demonstrative/deictic copula is formed by combining the spatial deictic stem hawla with the enclitic copula, e.g.

$\begin{array}{ll}\text { (24) } 3 \text { ms. } & \text { hawlele }(<\text { hawla }=\text { ile }) \\ \text { 3fs. } & \text { hawlala }(<\text { hawla }=\text { ila }) \\ \text { 3pl. } & \text { hawlala }(<\text { hawla }=\text { ila })\end{array}$

The spatial deictic stem hawla appears to be the result of two cycles of reanalysis. In the first cycle an original * $h \bar{a}-' a w$ deictic + demonstrative was reanalysed as a spatial deictic *haw with loss of referentiality of the demonstrative, as has been reconstructed for hole above. To this spatial deictic was added the 3 fs object L-suffix - $l a$ as an unspecified impersonal referential index. This combination of spatial deictic + impersonal referential index in turn underwent a cycle of reanalysis whereby the -la lost referentiality and the integrated form hawla became a spatial deictic. This was then inflected with the enclitic copula.

The C. Baz cluster of dialects form a sentential demonstrative/deictic copula by combining the enclitic copula with the spatial deictic stem haydo-. The historical background of this stem can be reconstructed as *hay-d-'aw, which contains the two deictic elements *hay and *d before the demonstrative pronoun *'aw:

(25) C. Bāz (Mahaye) $)^{36}$

$\begin{array}{lll}3 \mathrm{~ms} & \text { haydóle }<\text { *hay- } d \text {-'aw=ile } & \text { 'There he is' } \\ 3 \mathrm{fs} . & \text { haydóla }<\text { *hay- } d \text {-'aw=ile } & \text { 'There she is' } \\ \text { 3pl. } & \text { haydólay }<\text { *hay-d-'aw=ilay } & \text { 'There they are' }\end{array}$

The /d/ element may be an Aramaic deictic element, as in, for example, C. Bāz (Mahaye) 'adyo 'today' (< 'ad-yōm), or a Kurdish deictic element, such as di-, e.g. di-avá (DEIC-that) 'that one there', di-van (DEICthose) 'those there' (Urmi Kurmanji). ${ }^{37}$

A common form of the sentential demonstrative/deictic copula in several dialects in the northern sector of the NENA dialect area is wele. The spatial deictic stem we-in this form may be derived historically from *aw-hay-, i.e. a combination of a demonstrative pronoun *aw and the deictic element *hay, which appears in the form haydole of the Baz dialects. In some dialects the inflection of we-corresponds to the enclitic copula throughout the paradigm, e.g.

(26) C. Diz $^{38}$

\footnotetext{
$3^{2}$ Eleanor Coghill, 'Some Notable Features in North-Eastern Neo-Aramaic Dialects of Iraq', in Geoffrey Khan (ed.), Neo-Aramaic Dialect Studies (Piscataway: Gorgias, 2008) pp. 91-104.

${ }^{33}$ Jasmin Sinha, Der neuostaramäische Dialekt von Bēșpən (Provinz Mardin, Südosttürkei). Ein grammatische Darstellung (Wiesbaden: Harrassowitz, 2000).

${ }^{34}$ Shabo Talay, Die Neuaramäischen Dialekte der Khabur-Assyrer in Nordostsyrien: Einführung, Phonologie und Morphologie (Wiesbaden: Harrassowitz, 2008) pp. 197-198.

${ }^{35}$ Samuel Ethan Fox, The Neo-Aramaic Dialect of Bohtan (Piscataway: Gorgias, 2009).

${ }^{36}$ Hezy Mutzafi, 'The Neo-Aramaic Dialect of Maha Khtaya d-Baz. Phonology, Morphology and Texts', JSS 45.2 (2000), p. 305; Talay, Die Neuaramäischen Dialekte Der Khabur-Assyrer in Nordostsyrien, p. 199.

${ }^{37}$ Kurdish data supplied by Hiwa Asadpour.

${ }^{38}$ Talay, Die Neuaramäischen Dialekte Der Khabur-Assyrer in Nordostsyrien, p. 199.
} 


$\begin{array}{ll}\begin{array}{ll}\text { 3ms. } \\ \text { 3fs. } \\ \text { 3pl. }\end{array} & \begin{array}{l}\text { wele } \\ \text { wela }\end{array} \\ \text { wens. } & \\ \text { 2fs. } & \text { weta } \\ \text { 2pl. } & \text { weta } \\ & \text { wetun } \\ \text { 1s. } & \text { wena } \\ \text { 1pl. } & \text { wexa }\end{array}$

In a number of dialects the L-suffix of the inflection of the $3^{\text {rd }}$ person copula element is geminated, sometimes optionally. This gemination is likely to be a secondary development induced by stress, e.g.

(27) J. Challa ${ }^{39}$

$\begin{array}{lll}3 \text { ms. } & \text { walle } & \sim \text { wele } \\ 3 \text { fs. } & \text { walla } & \sim \text { wela } \\ \text { 3pl. } & \text { wallu } & \sim \text { welu }\end{array}$

In J. Challa and in several other dialects sentential demonstratives/deictic copulas of this form are used only in the $3^{\text {rd }}$ person, e.g. J. Zakho ${ }^{40}$ and C. Urmi. ${ }^{41}$

As with hole in some dialects, the L-suffix of the form walle/wele is in a number of dialects generalised throughout the paradigm. This was no doubt facilitated by the invariable stem of the construction, e.g.

\section{(28) J. Betanure ${ }^{42}$}

$\begin{array}{ll}3 \mathrm{~ms} . & \text { walle } \\ 3 \mathrm{fs} . & \text { walla } \\ 3 \mathrm{pl} . & \text { wallu } \\ \text { 2ms. } & \text { wallox } \\ 2 \mathrm{fs} . & \text { wallax } \\ 2 \mathrm{pl} . & \text { walloxun } \\ & \\ 1 \mathrm{1s} . & \text { walli } \\ \text { 1pl. } & \text { wallan }\end{array}$

In some dialects the sentential demonstrative/deictic copula distinguishes between far and near deixis, e.g.

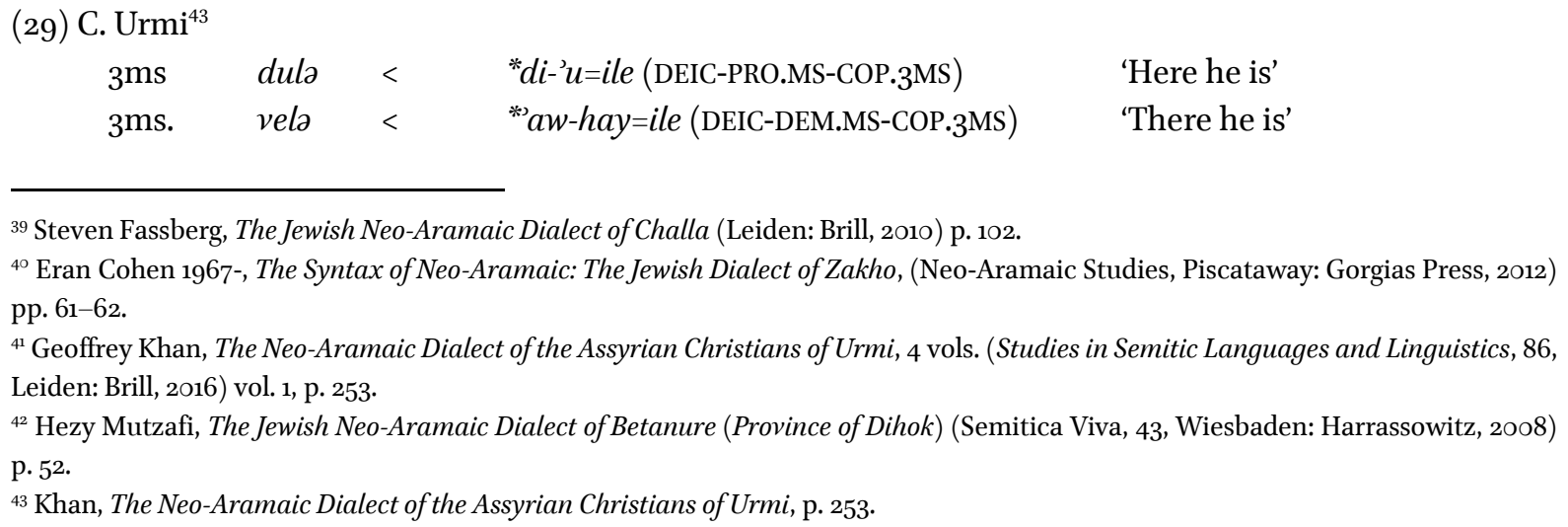

${ }^{39}$ Steven Fassberg, The Jewish Neo-Aramaic Dialect of Challa (Leiden: Brill, 2010) p. 102.

${ }^{40}$ Eran Cohen 1967-, The Syntax of Neo-Aramaic: The Jewish Dialect of Zakho, (Neo-Aramaic Studies, Piscataway: Gorgias Press, 2012) pp. 61-62.

${ }^{41}$ Geoffrey Khan, The Neo-Aramaic Dialect of the Assyrian Christians of Urmi, 4 vols. (Studies in Semitic Languages and Linguistics, 86, Leiden: Brill, 2016) vol. 1, p. 253.

${ }^{42}$ Hezy Mutzafi, The Jewish Neo-Aramaic Dialect of Betanure (Province of Dihok) (Semitica Viva, 43, Wiesbaden: Harrassowitz, 2008) p. 52 .

${ }^{43}$ Khan, The Neo-Aramaic Dialect of the Assyrian Christians of Urmi, p. 253. 
In some dialects completely different constructions are used for sentential demonstratives, on the one hand, and deictic copulas, on the other. One such dialect is C. Qaraqosh. The deictic copula in C. Qaraqosh is formed by combining a deictic particle $k$ - with the copula. ${ }^{44}$ The $k$ - is likely to be derived historically from a spatial adverbial with the form * $k \bar{a}$; cf. Syriac $k \bar{a}$ 'here' and related particle $k o$ - in Țuroyo:

$$
\begin{array}{ll}
\text { k-ila } & \text { 'here he is' } \\
\text { k-ila } & \text { 'here she is' } \\
\text { k-ina } & \text { 'here they are' }
\end{array}
$$

The C. Qaraqosh dialect expresses a sentential demonstrative by the combination of a demonstrative pronoun and an enclitic copula. The demonstrative may have near or far deixis, e.g.

$$
\begin{aligned}
& \text { Far deixis } \\
& \text { 'awela (< 'awa=ila) } \\
& \text { 'ayela (<'aya=ila) } \\
& \text { 'anena (<'ane=ina) } \\
& \text { Near deixis } \\
& \text { 'aðela (<'aða=ila) } \\
& \text { 'aðila (<'að }=\text { ila }) \\
& \text { 'anina (<'ani=ina) }
\end{aligned}
$$$$
\text { 'there he is' (literally: he is that one) }
$$$$
\text { 'there she is' (literally: she is that one) }
$$$$
\text { 'there they are' (literally: they are those) }
$$

$$
\begin{aligned}
& \text { 'here he is' (literally: he is this one) } \\
& \text { 'here she is' (literally: she is this one) } \\
& \text { 'here they are' (literally: they are these) }
\end{aligned}
$$

In C. Qaraqosh the demonstrative pronoun in such constructions can be combined with a $1^{\text {st }}$ or $2^{\text {nd }}$ person copula, e.g.

$$
\begin{array}{ll}
\text { 'aðeyən (<'ada=iyən) } & \text { 'here I am' (literally: I am this one) } \\
\text { 'aniyax (<'ani=iyax) } & \text { 'here we are' (literally: we are these) }
\end{array}
$$

This suggests that the demonstrative pronoun in such constructions has lost, or is in the process of losing, its referentiality as a $3^{\text {rd }}$ person pronoun and now has, or is in the process of acquiring, the function of a spatial deictic.

Some dialects have a construction for a sentential demonstrative but no deictic copula. This applies, for example, to many dialects spoken in the area of central Kurdish (Sorani). This is the case, for example, in the C. Sulemaniyya dialect, which has the sentential demonstrative construction 'ula:

(33) 'ula $<$ " $u=i l a$ (DEM.MS-COP.3FS) 'there/here he/she is', 'there/here they are'

This appears to be derived historically from a 3 ms pronoun ${ }^{*} u(<* h u)$ combined with the copula ila, which is morphologically 3 fs but has unspecified reference. So both the pronoun and the copula have lost specific referentiality, with the result that the construction is a spatial deictic with unspecified reference.

\subsection{The Thetic Function of the Deictic Copula}

In this section we shall take a closer look at the use of deictic copulas and related copula constructions. As we have seen in the preceding section, some NENA dialects have a construction that functions both as a

\footnotetext{
${ }^{44}$ Khan, The Neo-Aramaic Dialect of Qaraqosh, p. 128.
} 
sentential demonstrative and as a deictic copula (e.g. C. Barwar hole) whereas in other NENA dialects the deictic copula is a separate construction from the sentential demonstrative (e.g. C. Qaraqosh k-ile). In C. Barwar and C. Qaraqosh the deictic copulas take various types of clausal complements. The most commonly used types of complements are locative and eventive expressions (perfect and progressive), i.e. expressions with a specific locative or temporal deixis.

(34) C. Barwar ${ }^{45}$

(a) Yósap hóle tămàha. ${ }^{146}$

Yosəp DEIC.COP.3MS over.there

'Yosəp is over there'.

(b)

$\begin{array}{lll}\text { Yósəp } & \text { hóle } & g u-b \dot{\varepsilon} \vartheta a . \\ \text { Yosəp } & \text { DEIC.COP.3MS } & \text { in-house }\end{array}$

'Yosəp is in the house'.

(c) Yósap hóle ’àya.

Yosəp DEIC.COP.3MS come.PTCP.3MS

'Yosəp has come'.

\begin{tabular}{|c|c|c|}
\hline Yósəp & hóle & Эàya.! \\
\hline Yosəp & DEIC.COP.3MS & come.PROG \\
\hline
\end{tabular}

In locative expressions with hole there may be deixis to the speech situation, as in (34a), in which the locative adverbial tămaha 'over there' specifies where in the perceptible speech situation the referent is located. The locative construction is frequently used, however, in cases such as (34b), in which the referent is not necessarily in the perceptible environment. In perfect and progressive eventive expressions with hole $(34 \mathrm{c}-34 \mathrm{~d})$ the referent in question may be perceptible in the speech situation 'see he has come', 'see he is coming'. In many cases, however, these constructions are used to denote a situation that is not visibly perceptible in the extralinguistic environment. Unlike a sentential demonstrative construction that points to a referent in the speech situation, the deixis of the deictic copula encompasses both the referent and the spatial and temporal reference points of the locative and eventive modifying complements of such referents. This has resulted in the hole construction pointing to a situation involving a referent in association with a location or event rather than a referent alone.

Sentences with deictic copulas such as those in (34) are thetic sentences. As already remarked, a 'thetic sentence' presents a situation as an undivided whole. This differs from a 'categorical sentence', which consists of the bipartite act of naming an entity and the making an assertion about it. ${ }^{47}$ Thetic sentences, or more generally the category of utterance that Kaltenböck, Heine and Kuteva ${ }^{48}$ call theticals, are typically used by a speaker/writer to manage the discourse in his/her interaction with the reader/listener. They are often used, for example, to draw attention to a situation that forms the setting or background of the discourse. Sentences with a specific spatial and temporal deixis such as the locative and eventive constructions in (34), therefore, are particularly suitable as thetic sentences. The foreground of the discourse, by contrast, is typically advanced by categorical assertions.

\footnotetext{
${ }^{45}$ Khan, The Neo-Aramaic Dialect of Barwar, pp. 629-634.

${ }^{46}$ In the examples a grave accent marks nuclear stress, an acute accent marks non-nuclear stress and the symbol $\mid$ marks an intonation group boundary.

${ }^{47}$ Sasse, 'The Thetic/Categorical Distinction Revisited'.

${ }^{48}$ Gunther Kaltenböck, Bernd Hein and Tania Kuteva, 'On Thetical Grammar', Studies in Language 35.4 (2011), pp. 852-897.
} 
As has been discussed above, deictic copulas such a C. Barwar hole or C. Qaraqosh $k$-ile can be analysed as consisting of a spatial deictic element $\left(h o^{-}, k-\right)$ and an enclitic copula element. It is significant that in such constructions the enclitic copula element is bonded to the deictic element rather than to the following content item. Constructions that, by contrast, have an enclitic copula on the content items (35) should be interpreted as categorical sentences.

(35) (a) Yósap tàmele.

'Yosəp is there'.

(b) Yósap ’àyyzle.

'Yosəp came'.

The function of such categorical constructions is to make a predication about a referent. The referent is typically a topical referent that occurs in the preceding discourse. The categorical sentence advances the foreground of the discourse by making a predication about this referent. In C. Barwar a categorical locative sentence such as in (35a) is not commonly found and would be typically used to make an assertion about a permanent property of the subject referent that advances the discourse about Yosəp by adding more information about him. It would not act as spatio-temporal setting for what follows. The latter would be expressed by a thetic sentence containing a deictic copula (Yosap hole tama). A categorical eventive construction containing a participle such as $(35 \mathrm{~b})$ in C. Barwar would typically be used in a narrative to advance the foreground of the narrative. In such cases, the construction would not denote a resultative perfect but rather a perfective. ${ }^{49}$

Thetic sentences with the deictic copula hole are occasionally used in constructions with adjectival complements. Clauses with adjectival predicates are typically used categorically to attribute properties to the subject, and the copula is cliticised to the predicate. The deictic copula is used when the construction is used thetically to draw attention to a situation as a discourse strategy to provide preliminary background for the foreground that follows. This is the case with the hole clause in (36), which forms the grounds for the proposal made by the king to his brother:

$$
\begin{aligned}
& \text { málka máre țla-d-o-xóne făqira, máre xòni| } \\
& \text { baxtá } \vartheta \text {-ən hóla yaqúre tarwà̀n-a. } \\
& \text { wives-our DEIC.COP.3PL pregnant both-them } \\
& \text { 'ən-báxtux muӨéla bràtal 'u-báxti muӨéla bròna, brátux qa-bròni. 'ən-báxti muӨéla bràtal 'u-báxtux } \\
& \text { muӨéla bròna, 'a-bráti qa-brònux. }
\end{aligned}
$$

\subsection{Prominence Marking of the Copula}

The positioning of the copula on the spatial deictic component in the deictic copula in thetic sentences, on the one hand, and its placement on the predicate content item in categorical sentences, on the other, reflect differences of prominence of the content item. In the C. Barwar dialect, and many other NENA dialects, the enclitic copula can occur in various positions in the clause. Its position endows its host with prominence. It is, therefore, not only a copula but also a prominence marker. In categorical sentences it is placed on the predicative content item, which is, therefore, marked as salient (Yosap tamele), reflecting clearly the bipartite distinction between the predication and the base of predication (to use the terminology of Sasse 1987). In thetic sentences such as Yosap hole tama it is the spatial deictic exponent ho- that is marked as salient. The predicative content item correspondingly is presented with a lesser, demoted degree of salience. This reflects a demotion of the predication in a thetic sentence and its lesser degree of distinctness, reducing the

\footnotetext{
${ }^{49}$ Khan, The Neo-Aramaic Dialect of Barwar, pp. 669-672.

${ }^{50}$ C. Barwar, Khan, The Neo-Aramaic Dialect of Barwar, p. 632.
} 
bipartiteness of the construction, with the effect that the sentence presents a unitary situation rather than making a predication about a referent.

Sasse ${ }^{51}$ has examined various strategies that are used in thetic sentences in various languages in order to demote the predicative component of the sentence. One such strategy, which has some similarity to the positioning of the copula in the NENA dialects, is the use of cleft constructions in some languages to express thetic sentences describing a situation. He cites, ${ }^{52}$ for example, colloquial French constructions such as (37), which denotes an event, i.e., an eventive situation. To these I have added (38), from my own collected data, which is equative, and denotes a non-eventive situation. The nuclear stress, which is represented by upper case, is placed at the end of the construction:

Qu'est-ce qu'ily a?-C'est maman qui me BAT.

'What's the matter? —Mum's hitting me (eventive)'.

(38) J'aifaim-C'est cet homme là-bas qui est le CHEF. Il te donnera de bonne nourriture.

'I am hungry— That man there is the chef (equative). He will give you good food.'.

According to Sasse, in such constructions the clefting has the effect of giving prominence to the whole situation expressed by the sentence. The sentence is, therefore, thetic. Since in thetic sentences the whole content of the proposition is made prominent, they are also termed sentence-focus constructions, as opposed to predicate-focus constructions in which specifically the predicate is made prominent. ${ }^{53}$ The thetic-categorical distinction is, however, independent of the information structure of the components of the sentence. Sasse $\mathrm{e}^{54}$ points out that the thetic-categorical distinction relates to 'the general shape a speaker gives the state of affairs' and so relates to the sentence, whereas information structure relates to the text. Some components in a thetic sentence can, therefore, be contextually bound. The clefting of sentences such as (37) and (38) into two components has the effect of subordinating the assertion of the predicate syntactically and pragmatically to the initial entity, and so it is not a main predication. Rather it is a predication of the type found in a dependent clause, viz. a non-assertive predication without illocutionary force.

\subsection{Thetic vs Contrastive Constructions}

It is important to note that in thetic cleft constructions such as $(37)$ and $(38)$ the initial item is not in contrastive focus, with the content of the subordinate clause presuppositional. A contrastive reading of C'est MAMAN qui me bat, with the nuclear stress on Maman, would convey that I assume that you know that somebody is hitting me, and I am asserting that the somebody is Mum, not anybody else you may have been considering for the role. Cleft constructions can indeed be used with this function, but in thetic clefts the content of the subordinate clause is informative, although its assertiveness is demoted. It is, indeed, the syntactic subordination that demotes the assertiveness of the clause, since the content of such subordinate relative clauses in cleft constructions are typically presuppositional. Cleft sentences that have an informative rather than presuppositional subordinate clause are also used in English and have been studied by various scholars. ${ }^{55}$ These can occur in discourse-initial position, as in (39), and also within the discourse, as in (40) (cited by Hedberg 1990, 139-72):

\footnotetext{
${ }^{51}$ 'The Thetic/Categorical Distinction Revisited'.

${ }^{2}$ 'The Thetic/Categorical Distinction Revisited', pp. 538-544.

${ }^{53}$ Knud Lambrecht and Maria Polinsky, 'Typological Variation in Sentence-Focus Constructions', in Kora Singer, Randall Eggert, and Gregory Anderson (eds.), Papers from the Panels on Linguistic Ideology in Contact, Universal Grammar, Parameters and Typology, the Perception of Speech and Other Acoustic Signals (CLS, 33, Chicago: Chicago Linguistic Society, 1997) pp. 189-206.

${ }^{54}$ Sasse, 'The Thetic/Categorical Distinction Revisited', p. 518.

${ }_{55}$ Ellen F. Prince, 'A Comparison of Wh-Clefts and It-Clefts in Discourse', Language 54 (1978), pp. 883-9o6; Nancy Hedberg, 'Discourse Pragmatics and Cleft Sentences in English' (Thesis, University of Minnesota, 1990) pp. 139-173.
} 
It was the Greeks who first made wine around 1500 BC.

(40) She saved your neck and my reputation. It was she who found your overcoat.

In these examples the constructions do not put narrow contrastive focus on the cleft constituents to contrast them with a set of other candidates for the role that is salient in a presupposition. Prince (1978) terms such constructions "informative-presupposition" clefts. They can be identified as thetic sentences: (39) lays the grounds for what follows and (40) presents explanatory material.

In the C. Barwar NENA dialect contrastive focus in a copula sentence may be expressed by attaching the copula to the item in contrastive focus, which bears the nuclear stress of the intonation group (represented by upper case in the translation), e.g.

(41) Yòsap=ile táma. 'JOSEPH is there' (not anybody else you may be considering)

The construction in (41) consists of a presuppositional component ('I assume that you are thinking that somebody is there') and an assertive component ('that somebody is Joseph'). ${ }^{56}$ This should be interpreted, therefore, as a categorical sentence, with a bipartite structure. The base of predication is the variable in the presupposition 'the somebody who is there' and the predication consists of the act of specifying the value of this variable. This, therefore, is a 'specificational' predication. In the general theoretical literature on copula sentences a distinction is often made between 'specificational' copula sentences, which assign a value to a variable, as here, and 'predicational' sentences, which assign a property to an entity. ${ }^{57}$ It is important to note, therefore, that by using the terminology of Sasse 'base of predication' - 'predication' to describe the bipartite division of categorical sentences, we are using the term 'predication' in the broader sense of 'making a statement about' rather than 'assigning a property to'.

\subsection{Cleft Sentences and Focus Markers}

A construction such as (41) could be expressed by a cleft construction in English and French: It isJOSEPH who is there; C'est JOSEPH qui est là. It is relevant to point out that in some languages the biclausal structure of a cleft sentence is reduced to a monoclausal structure by the loss of the subordinate marker. The copula element then turns into what is referred to in the literature as a 'constituent focus marker'.$^{8}$ An example of this from Haitian Créole French cited by Heine and Kuteva is as follows. The focus is represented in the translations below by upper case:

\begin{tabular}{|c|c|c|c|c|c|c|}
\hline \multicolumn{7}{|c|}{ Haitian Créole French ${ }^{59}$} \\
\hline $\mathrm{Se}$ & sou & chen & $m \grave{e} g$ & yo & $w e ̀$ & pis \\
\hline FOC & LOC & $\operatorname{dog}$ & thin & $3^{\mathrm{PL}}$ & see & flea \\
\hline
\end{tabular}

\footnotetext{
${ }^{56}$ For such contrastive constructions in J. Zakho, see Cohen 'Syntactic Focus Marking in Jewish Zakho Neo-Aramaic', in Geoffrey Khan (ed.), Neo-Aramaic Dialect Studies (Piscataway: Gorgias, 2008) pp. 149-169.

${ }^{57}$ Francis Roger Higgins, The Pseudo-Cleft Construction in English (New York: Garland, 1979); Line Mikkelsen, 'Copular Clauses', in Klaus von Heusinger, Claudia Maienborn, and Paul Portner (eds.), An International Handbook of Natural Language Meaning (Handbooks of Linguistics and Communication Science [HSK], 33/2, Berlin: De Gruyter, 2011) vol. 2, pp. 1805-1829.

${ }^{8}$ Alice C. Harris and Lyle Campbell, Historical Syntax in Cross-Linguistic Perspective (Cambridge: Cambridge University Press, 1995) pp. 152-165; Bernd Heine and Tania Kuteva, World Lexicon of Grammaticalization (Cambridge: Cambridge University Press, 2002) pp. 95-96.

${ }^{59}$ Pieter Muysken and Tonjes Veenstra, 'Serial Verbs', in Jacques Arends, Pieter Muysken, and Norval Smith (eds.), Pidgins and Creoles: An Introduction (Creole Language Library, 15, Amsterdam: John Benjamins, 1995) pp. 289-301; cited in Heine and Kuteva, World Lexicon of Grammaticalization, pp. 95-96.
} 
Here the focus marker se has its origin in French c'est. The corresponding structure in standard French would have the relativiser: C'est sur un chien maigre qu'ils voient les puces.

The positioning of the copula in a NENA dialect such as C. Barwar has a typological resemblance to the use of a copula as a focus marker in monoclausal constructions such as (42), although there is no evidence that the focus-marking function of the NENA copula developed diachronically from biclausal cleft constructions.

\subsection{Spatio-temporal Indexing}

Returning to thetic sentences such as C. Barwar Yósap hóle gu-bì̀ $\vartheta$ ' 'Joseph is in the house', we have seen that such constructions with the deictic copula are typically used when attention is drawn to a situation with a specific spatio-temporal index, i.e. a contingent situation. This is one of the reasons why the focus-marking copula is placed on the deictic element ho-. The same applies to C. Qaraqosh, in which the equivalent thetic sentence would have the deictic copula k-ile, viz. Yósap k-ila b-bè̀a. Thetic sentences that manage discourse by laying the grounds for what follows or by presenting explanatory background are not always necessarily contingent situations. It is possible to present a permanent situation, which is not tied to a specific spatiotemporal index, as the background of the adjacent foreground discourse. This applies, for example, to the thetic French cleft C'est cet homme là-bas qui est le chef, 'That man there is the chef', which is cited in (38) above. In some NENA dialects, such thetic copula sentences expressing permanent situations, which are typically equative or classificatory, are constructed by the placement of the copula on the initial subject item rather than the predicate. This applies, for example, to C. Qaraqosh, where the construction is often used with clauses with independent subject pronouns, e.g.

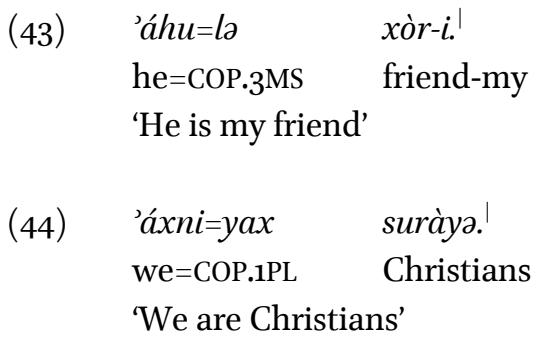

It is important to note that the subject items here are not in contrastive focus. Rather they are given non-contrastive salience and the following content of the clause is informative. The effect of this, as discussed above, is to demote the assertiveness of the following content, thus packaging the clause as a unitary situation, rather than the bipartite assertion of information about a particular topic. Analogously to informative presuppostion cleft constructions, to use Prince's (1978) terminology, the material after the copula has the status of an informative presupposition. Such constructions are typically used to lay the grounds for what follows or present explanatory material. Explanatory thetic sentences sometimes occur in responses to questions, as in (45):

(45) kpáya mày=la?

hearth what $=$ COP.3FS

'áhi=la dùkal k-ódi-wa-la b-țina.

PRO.3FS=COP. place IND-do.IPFV-PST-OBJ.3FS with-mud

'What is a kpaya (hearth)? It is a place that they used to make out of mud ${ }^{36}$

Equivalent constructions with the copula on the predicate would be categorical sentences, making predications about a topical referent, typically to advance the foreground of discourse:

\footnotetext{
${ }^{60}$ Khan, The Neo-Aramaic Dialect of Qaraqosh, p. 405.
} 
(46) 'áhu xòr-i=ila.!

he friend-my=COP.3MS

'He is my friend'

(47) 'áxni suràyz=yax.!

we Christians=COP.1PL

'We are Christians'

\subsection{Thetic Extrapositional Constructions}

In C. Qaraqosh the enclitic copula is occasionally attached also to an initial nominal subject in a thetic sentence expressing a permanent situation, e.g.

$$
\begin{aligned}
& \text { Máyu=la šámš-əd mà } a \text {. } \\
& \text { Mayu=COP.3FS sun-CST village } \\
& \text { 'Mayu is the sun of the town' }{ }^{61}
\end{aligned}
$$

More frequently, however, when the subject is a nominal, the subject is extraposed and resumed by a

\begin{tabular}{|c|c|c|}
\hline & \multicolumn{2}{|c|}{ mày=la? } \\
\hline $\begin{array}{l}\text { grinding.wheel } \\
\text { dánək }\end{array}$ & & $\begin{array}{l}\text { OP.3MS } \\
\text { 'áhu=la }\end{array}$ \\
\hline $\begin{array}{l}\text { grinding.wheel } \\
\text { k-maxðir-ə }\end{array}$ & $\mathrm{P}$ & $\begin{array}{l}\text { RO.3MS=COP.3MS } \\
\text { sùso! }\end{array}$ \\
\hline IND-turn.IPFV-OB & $\mathrm{J} \cdot 3 \mathrm{M}$ & horse \\
\hline
\end{tabular}
subject nominal with an enclitic copula as in (49):

'an-kipa rábal

from-stone big

'What is a grinding wheel?' A grinding wheel is (made) of a large stone, which a horse turns' (Khan

\begin{tabular}{|c|c|c|}
\hline Baġdèdal & 'áhi=la & 'atáqta hèlal \\
\hline Bağdedə & $\mathrm{PRO} .3^{\mathrm{FS}}=\mathrm{COP} .3 \mathrm{FS}$ village & ancient very \\
\hline
\end{tabular}
2002, 412)

As with other thetic sentences, such constructions typically function as explanatory background statements (49) or statements that present a situation that sets the scene for what follows $\left(5^{\circ}\right)$. The extraposition of lexical subjects in these constructions is a further strategy to give salience to the subject as the topical pivot of the situation presented in the thetic sentence and, correspondingly, to demote the assertion of the following content. A pronoun is inherently more topical, i.e. its referent is more accessible, than a lexical nominal phrase, so a nominal phrase requires the additional extraposition strategy to raise its topical prominence. They can be regarded as analogous in structure also to thetic constructions with the deictic copula $k$-ila, in that the ordering of the elements is the same, except the resumptive pronoun occurs before the copula rather than the spatial deictic element $k$ -

In C. Barwar thetic copula sentences that present a permanent situation occasionally have the copula cliticised to the subject. This is found mainly when the subject is pronominal, e.g.

$$
\begin{array}{ll}
\text { 'áyys=la } & \text { čita. } \\
\text { this=COP.3FS } & \text { butter } \\
\text { 'This is butter } &
\end{array}
$$

\footnotetext{
${ }^{61}$ Khan, The Neo-Aramaic Dialect of Qaraqosh, p. 404.

${ }^{62}$ Khan, The Neo-Aramaic Dialect of Barwar, p. 628.
} 
More frequently the copula stands independently before the predicate in constructions such as the following:

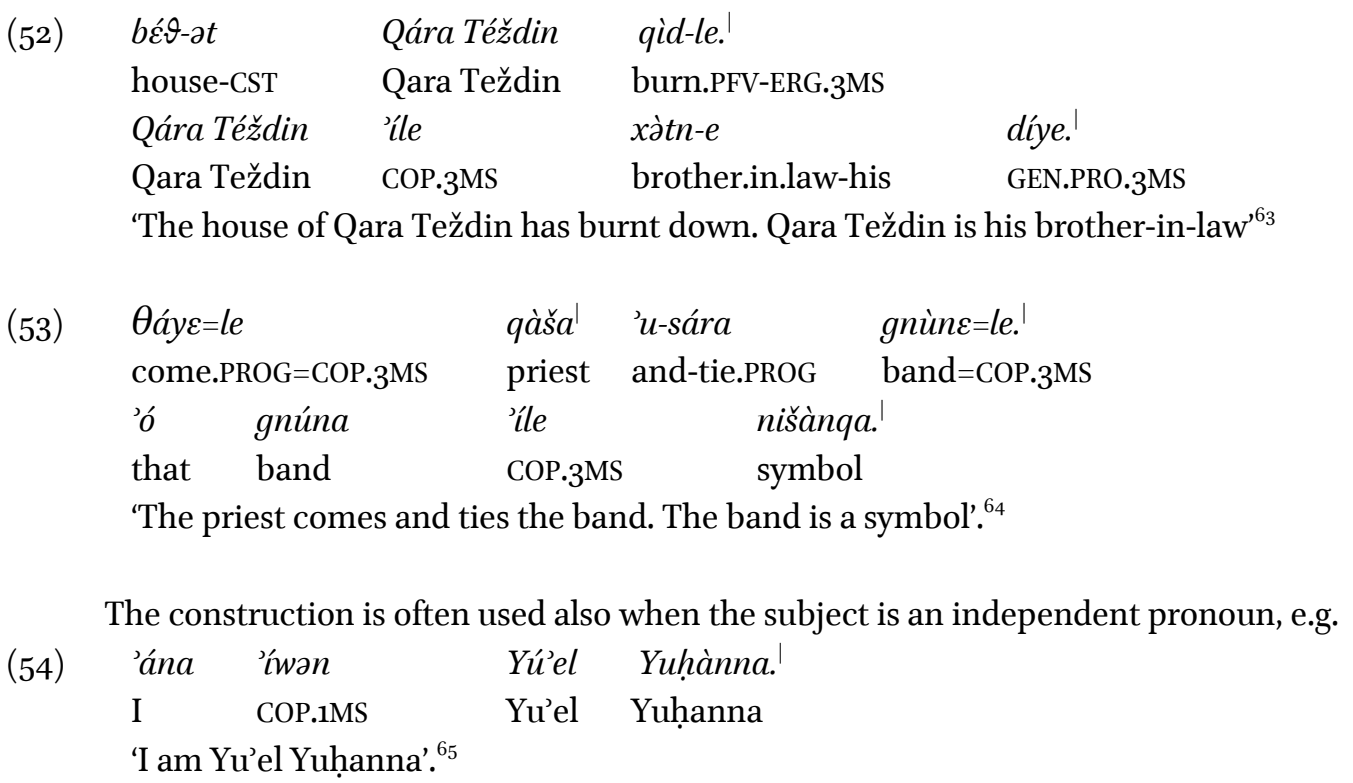

Such constructions have the typical functions of thetic sentences, e.g. the provision of explanatory material $\left(5^{2-53}\right)$ or of preliminary material at the beginning of a discourse section (54). Their structure is analogous to the extrapositional thetic constructions used in the C. Qaraqosh dialect $(49-50)$. The placement of the copula before the predicate rather than cliticised to the end of the predicate demotes the salience of the predicate, as is the recognised strategy in thetic sentences. The prosodic separation of the subject item and the copula can be regarded, correspondingly, as a strategy to enhance the topic prominence of the subject, doubly indexing it with two adjacent stressed items. These types of constructions can be regarded as analogous in structure also to constructions with hole, in that the ordering of the elements is the same, except that the copula occurs without the spatial deictic element ho-.

\subsection{Dialects Using Basic Copula in Locative and Eventive Thetic Sentences}

In some NENA dialects the bare copula without a spatial deictic element is used before the predicate of locative and eventive thetic constructions, which express a contingent situation. This is the case, for example, in J. Betanure, e.g.

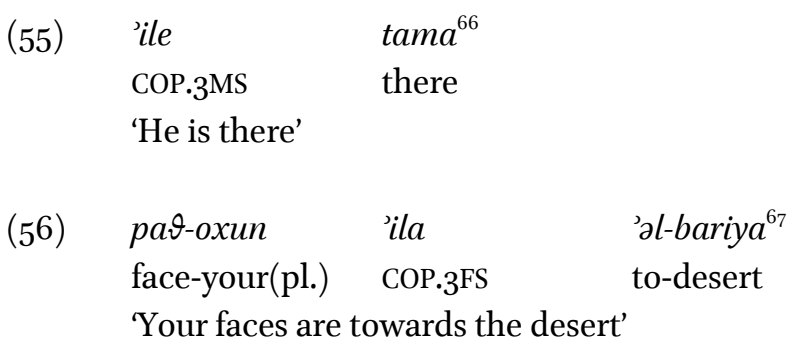

\footnotetext{
${ }^{63}$ Khan, The Neo-Aramaic Dialect of Barwar, p. 628.

${ }^{64}$ Khan, The Neo-Aramaic Dialect of Barwar, p. 628.

${ }^{65}$ Khan, The Neo-Aramaic Dialect of Barwar, p. 628.

${ }^{66}$ Mutzafi, The Jewish Neo-Aramaic Dialect of Betanure (Province of Dihok) p. 44.

${ }^{6}$ Mutzafi, The Jewish Neo-Aramaic Dialect of Betanure (Province of Dihok) p. 300.
} 
(57) 'ile

\begin{tabular}{|c|c|}
\hline ile & วงya \\
\hline OP.3MS & come.PTCP.MS \\
\hline
\end{tabular}

(58) 'ile

biจaya ${ }^{69}$

COP.3MS

come.PROG

'He is coming'

The initial ' $i$ - of the copula is sometimes elided, e.g.

(59) le
COP.3MS
come.PTCP.MS

วəya

'He has come'

In such constructions the deictic copula with the spatial deictic element may optionally be used, ${ }^{70}$ e.g.
(6o) walle ’aya
DEIC.COP.3MS come.PTCP.MS
'He has come'

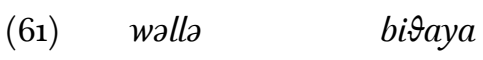

DEIC.COP.3MS come.PROG

'He is coming'

In J. Betanure when a copula is combined with a resultative participle it may be placed either before the participle or placed after it as an enclitic. According to Mutzafi ${ }^{71}$ the former is a 'dynamic perfect' whereas the latter is a 'stative perfect'. This can be interpreted as corresponding to the thetic — categorical distinction. When the copula is placed before it, the construction is thetic and presents an eventive situation (62). When it is enclitic, the construction is categorical and predicates a stative attribute of the subject (63):

(62) 'ile

COP.3MS leave.PTCP.MS

'He has left'

(63) šwiqa=ile

leave.PTCP.MS=COP.3MS

'He is left'

In some dialects the copula is cliticised to the subject item in eventive thetic constructions, e.g.

(64) C. Mez

'axni=x zala

we=COP.1PL go.PROG

We are going'

\footnotetext{
${ }^{68}$ Mutzafi, The Jewish Neo-Aramaic Dialect of Betanure (Province of Dihok) p. 79.

${ }^{69}$ Mutzafi, The Jewish Neo-Aramaic Dialect of Betanure (Province of Dihok) p. 79.

$7^{\circ}$ Mutzafi, The Jewish Neo-Aramaic Dialect of Betanure (Province of Dihok) p. 57.

${ }^{71}$ Mutfazi, The Jewish Neo-Aramaic Dialect of Betanure (Province of Dihok) pp. 56-57.
} 
(65) J. Amedia.

$\begin{array}{ll}\text { 'awe }=l e & \text { 'a } \vartheta y a \\ \text { he=COP.3MS } & \text { come.PTCP.MS } \\ \text { 'He has come' } & \end{array}$

$\begin{array}{llll}\text { Šalom } & \text { ben } & \text { Moše=le } & \text { mira } \\ \text { Šalom } & \text { son } & \text { Moše=COP.3MS } & \text { say.PTCP.MS }\end{array}$

‘Šalom son of Moše has said ${ }^{72}$

\subsection{Kurdish Parallels}

It is likely that the use of the basic copula before the predicate in thetic sentences that are predominantly locative and eventive in dialects such as J. Betanure, J. Amedia and C. Mez has been influenced by the syntax of copula sentences in the Kurdish dialects of the region. The NENA dialects where this feature occurs are (or were) located predominantly in the region where the Bahdini variety of Northern Kurdish is spoken, i.e. around the townships of Zakho, Dohuk and Amedia in northern Iraq. In Bahdini Kurdish a relative demonstrative particle known as the ezafe has come to be used as a copula, in particular in locative and eventive predicates. ${ }^{73}$ The ezafe particle is either independent or attached to the initial subject item, e.g.

Ergin $y \hat{e} \quad$ l-mal $~ \quad$ Ergin-ê l-mal
Ergin EZ.MS in-house
'Ergin is in the house'

Ergin $y \hat{e} \quad$ hatî $~$ Ergin-ê hat $̂$
Ergin EZ.MS come.PTCP
'Ergin has come'

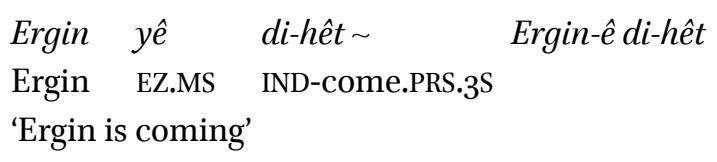

Such locative and eventive constructions can be interpreted as thetic sentences, referring to a situation rather than making a predication about the subject. The ezafe is in origin an attributive-relative particle. A sentence such as (66), therefore, would have originally had the structure 'Ergin (is) one who is in the house'. This is likely to have originated as a thetic cleft construction with an informative presupposition, as a strategy to demote the predicate in the manner described above (e.g. in colloquial French). The construction is now, however, monoclausal and the ezafe has been reanalysed as a copula. The development of the thetic constructions in the NENA dialects with the copula before the predicate in the Bahdini area, predominantly in locative and eventive clauses, is likely to have been facilitated by matching the pattern of the NENA copula with that of the Bahdini ezafe copula. Central Kurdish dialects (Sorani) have the inherited Iranian copula, which is normally cliticised to the predicate. It is significant that in NENA dialects spoken in the area of Central Kurdish the copula is regularly an enclitic on the predicate and is never placed independently before the predicate.

\footnotetext{
${ }^{72}$ Jared R Greenblatt, The Jewish Neo-Aramaic Dialect of Amadiya (Studies in Semitic Languages and Linguistics, 61, Leiden: Brill, 2011) p. 276 .

${ }^{73}$ David N. MacKenzie, Kurdish Dialect Studies, vols. 9-10 (London Oriental Series, London: Oxford University Press, 1961) pp. 210-211; Geoffrey Haig, 'Linker, Relativizer, Nominalizer, Tense-Particle. On the Ezafe in West Iranian', in Fung Ha Yap, Karen Grunaw-Hårsta, and Janick Wrona (eds.), Nominalization in Asian Languages: Diachronic and Typological Perspectives. (Amsterdam: John Benjamins, 2011) pp. 363-39o.
} 


\subsection{Neutralisation of Referential Indexes of Copula}

In a number of NENA dialects the referential index of person, number and gender of the preposed copula in thetic sentences has been neutralised. The outcome of this is an invariable form that is in most cases derived

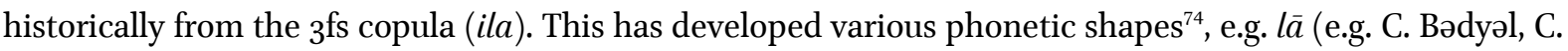
Koy Sanjak, J. Arbel, J. Ruwanduz, J. Rustaqa), $n \bar{a}$ (J. Dobe, J. Hiza), $n a$ (C. Aqra, C. Shaqlawa). The J. Barzan cluster of dialects has the invariable form 'ale, ${ }^{75}$ which appears to have developed from a combination of a deictic element ${ }^{*} h \bar{a}$ - and the invariable $3^{\text {rd }}$ person copula form $l e\left(<{ }^{*} i l e\right)$. We have seen the neutralised use of the 3 fs above in deictic elements in various dialects, e.g. C. Bohtan hawla and the C. Sulemaniyya 'ula. The neutralisation of the referential index of the copula has resulted in particles such as $l \bar{a}, n \bar{a}, n a$ having the function of deictic particles rather than copulas. This is shown by the fact that in some dialects $1^{\text {st }}$ and $2^{\text {nd }}$ person reference is now marked by an enclitic copula on the predicate, e.g.

(69) C. Bədyəl

$$
\begin{aligned}
& l \bar{a} \quad \text { gu-beta } \\
& \text { DEIC in-house } \\
& \text { 'He/she/they is/are in the house' }
\end{aligned}
$$

(70) lā gu-bete=wat

DEIC in-house $=$ COP.1MS

'I (m.) am in the house'

(71) lā gu-bete=wan

DEIC in-house $=$ COP.2MS

'You (ms.) are in the house'

This neutralisation is likely to have been the result of a greater degree of convergence with the pattern of the Bahdini Kurdish ezafe copula. The ezafe copula is neutral as to person and, moreover, in some dialects it has lost distinctions of gender and number and is invariable in form. ${ }^{76}$

\subsection{Preposing of Copula in Relative Clauses}

Finally, this discussion of the function of the preposing of the copula in clauses is relevant for understanding the syntax of the copula in relative clauses. In many NENA dialects the copula is cliticised to the relative

\begin{tabular}{|c|c|c|c|}
\hline 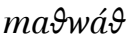 & $d=i n a$ & xáðran & Bag̀dèda \\
\hline villages & $\mathrm{REL}=\mathrm{COP} \cdot 3^{\mathrm{PL}}$ & around & Bağdedə \\
\hline
\end{tabular}
particle at the front of a relative clause rather than on the predicate, e.g.

(72) Qaraqosh ${ }^{77}$

We may interpret such constructions in NENA as the use of the copula to express prominence on the relative particle, coindexed with the antecedent noun, as a strategy to demote the assertion of the clause. This would be the same strategy that we have seen in several contexts throughout this paper. The motivation to express demotion of the assertion of the clause is here not because the clause is thetic, but rather on

\footnotetext{
${ }^{74}$ Geoffrey Khan, A Grammar of Neo-Aramaic: The Dialect of the Jews of Arbel (Boston, MA: Brill Academic Publishers, 1999); Hezy Mutzafi, 'Features of the Verbal System in the Christian Neo-Aramaic Dialect of Koy Sanjaq and Their Areal Parallels', JAOS 124.2 (2004), pp. 249-264.

${ }^{75}$ Hezy Mutzafi, 'Barzani Jewish Neo-Aramaic and Its Dialects', Mediterranean Language Review 14 (2002), pp. 41-70; Hezy Mutzafi, 'Two Texts in Barzani Jewish Neo-Aramaic', BSOAS 67.1 (2004), pp. 1-13.

${ }^{76}$ Haig, 'Linker, Relativizer, Nominalizer, Tense-Particle. On the Ezafe in West Iranian'.

${ }^{77}$ Khan, The Neo-Aramaic Dialect of Qaraqosh, p. 475.
} 
account of the fact that restrictive relative clauses are non-assertive. Once it had developed in restrictive relative clauses, it was subsequently extended to non-restrictive relative clauses, e.g.

$\begin{array}{lll}\text { (73) } \text { Qaraqosh }^{78} & & \\ \text { șálm-ah } & d=\text { ila } & \text { bahùra } \\ \text { face-her } & \text { REL=COP.3MS } & \text { radiant } \\ \text { her face, which is radiant' } & \end{array}$

It is possible that contact with Northern Kurdish dialects with the ezafe type of copula had an impact on the development of these constructions. In such dialects the ezafe element can stand at the head of a relative clause and function both as a copula and as a relative pronoun, e.g.

\begin{tabular}{|c|c|c|c|c|}
\hline $\begin{array}{l}\text { meriv } \\
\text { man }\end{array}$ & $\begin{array}{l}y \hat{e} \\
\text { EZ.MS }\end{array}$ & $\begin{array}{l}\text { l-mal } \\
\text { in-house }\end{array}$ & $\begin{array}{l}\text { hawal-êe } \\
\text { friend-Ez }\end{array}$ & $\begin{array}{l}\min =a \\
\mathrm{me}=\mathrm{COP} .3 \mathrm{~S}\end{array}$ \\
\hline
\end{tabular}

In Central Kurdish and in NENA dialects spoken in the area of Central Kurdish, by contrast, the copula is regularly placed on the predicate of relative clauses.

\section{Conclusions}

The extension of the original $3^{\text {rd }}$ person pronominal element /i/ throughout the paradigm of the enclitic copula indicates that it was no longer analysed as the $3^{\text {rd }}$ person inflection but was reanalysed as the stem of the copula.

The $3^{\text {rd }}$ person inflection of the copula originated as an L-suffix with the function of an object pronoun in a sentential demonstrative construction, drawing attention to a referent (ho-le 'there he is').

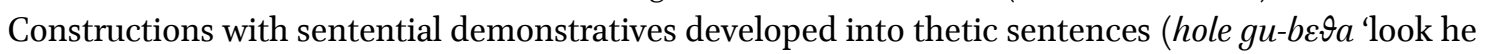
is in the house'). A 'thetic sentence' presents a situation as an undivided whole. This differs from a 'categorical sentence', which consists of the bipartite act of naming an entity and the making an assertion about it. When the construction came to be interpreted as a thetic sentence, the object L-suffix came to be reanalysed as the inflection of a copula, resulting in the emergence of a deictic copula. This development originated in constructions with $3^{\text {rd }}$ person referents outside the speech situation, and that is why the inflection of the copula with L-suffixes is restricted to the $3^{\text {rd }}$ person in most dialects. The inflection of the deictic copula with L-suffixes was then extended to the enclitic copula.

Thetic sentences are used to manage the discourse. Typically they draw attention to a situation that forms the setting or background of the discourse. The foreground of the discourse, by contrast, is typically advanced by categorical assertions.

Deictic copulas are used to express thetic sentences, whereas sentences with the copula cliticised to the predicate are typically used as categorical sentences.

Another means of expressing a thetic copula sentence is to attach the enclitic copula to an initial subject rather than the predicate. The enclitic copula endows its host with salience. The placement of the copula on the initial subject in thetic sentences reflects the demotion of the predication and its lesser degree of distinctness, reducing the bipartiteness of the construction, with the effect that the sentence presents a unitary situation rather than making a predication about a referent. In some dialects the copula placed before the predicate in thetic sentences is prosodically independent and not an enclitic of the subject. In a number of such dialects the preposed copula has lost its person indexing.

\footnotetext{
${ }^{78}$ Khan, The Neo-Aramaic Dialect of Qaraqosh, p. 476.
} 